\title{
Analisis Strategi Cina Melakukan Foreign Direct Investment (FDI) berbasis Minyak dengan Sudan Tahun 2009
}

\author{
Syelda Titania Sukarno Putri, Gamaly, Yolanda Dwi
}

\author{
Program Studi Hubungan Internasional, Universitas Muhammadiyah Malang - Indonesia \\ Email: syeldaputri98@gmail.com \\ Diserahkan: 02 April 2019| Diterima: 24 April 2019
}

\begin{abstract}
The rapid economic growth of China during the last two decades, has prompted its dependence on oil imports exceeding its domestic production. China for the first time exceeded the US position as the biggest oil importer in 2015 in Africa region particularly Sudan. Chinese oil investment in Sudan then become an international concern because China's non-intervention policies are considered irresponsible of domestic problems in Sudan. This research attempts to explain Cina's strategic interaction with conflict-troubled Sudan using three analytical variables, (i) the identification of state interest; (ii) the specification of strategic setting with Cina First; and (3) the impact of the Cina investment to Sudan. The analysis result shows that Cina's need for oil to secure its economic growth is Cina's vital interest as being prioritized by they strategic based on Cina's First policy that is permissive towards Sudan's domestic issue.
\end{abstract}

Keywords: Oil, Investment, China, Sudan, Strategy, Economy.

\begin{abstract}
Abstrak
Pertumbuhan ekonomi Cina yang sangat pesat dalam dua dekade terakhir mendorong tingginya ketergantungan Cina akan impor minyak bumi melebihi kapasitas produksi domestiknya. Cina untuk pertama kalinya melampaui posisi Amerika Serikat sebagai importir minyak terbesar di dunia pada tahun 2015 di kawasan Afrika seperti Sudan. Investasi minyak Cina di Sudan kemudian menjadi perhatian dunia internasional karena kebijakan non-intervensi Cina dianggap tidak memperdulikan permasalahan domestik yang ada di Sudan. Penelitian ini berupaya untuk menjelaskan bagaimana investasi minyak Cina di Sudan dengan fokus analisis pada tiga variabel analisis, (i) identifikasi terhadap kepentingan negara; (ii) spesifikasi strategis melalui China First; dan (iii) dampak investasi Cina terhadap Sudan. Hasil analisis memperlihatkan bahwa kebutuhan minyak sebagai penggerak pertumbuhan ekonomi Cina merupakan kepentingan krusial sehingga menjadi prioritas yang dilakukan Cina sebagai kebijakannya yang berdasarkan Cina First yang permisif terhadap isu domestik negara lain.
\end{abstract}

Kata Kunci: Minyak, Investasi, Cina; Sudan, Strategi, Ekonomi.

\section{PENDAHULUAN}

Kemajuan Cina yang semakin pesat di era globalisasi ini selalu menarik perhatian masyarakat dunia untuk dijadikan subjek analisis. Hal yang paling menonjol dalam kemajuan Cina adalah peningkatan kebutuhan energi untuk mempertahankan kebutuhan produksi ekonomi nasional. Pada praktiknya, pemerintah Cina selalu berupaya untuk memperluas investasi dan kerjasama kepada negara-negara penghasil minyak untuk memenuhi pasokan energi nasional. Hal ini sekaligus 
menandai bahwa saat ini Cina sangat tergantung terhadap energi minyak. Ketergantungan Cina terhadap minyak tersebut bahkan melampaui posisi Amerika Serikat sebagai negara pengonsumsi minyak terbesar di dunia (Kusuma, 2008). Perlombaan industri yang sedang terjadi saat ini mendorong mayoritas negara-negara di dunia untuk memperluas kerjasama dalam bidang energi. Interaksi yang terjadi antar aktor negara maupun nonnegara, seperti organisasi internasional dalam jangka waktu ke depan akan dipengaruhi oleh faktor-faktor sumber daya energi (Kompas, 2007). Melihat persaingan energi yang sangat tinggi, Cina saat ini merubah haluan kebijakan investasi tidak lagi kepada negaranegara di kawasan Timur Tengah, melainkan kepada Afrika. Dengan adanya perubahan orientasi kebijakan luar negeri, Cina mendapatkan 25\% dari total ekspor minyak Afrika, terutama yang berasal dari Sudan. Upaya Cina untuk memenuhi kebutuhan energi dalam negeri ditempuh kunjungan-kunjungan dipomatik, dan kebijakan-kebijakan Cina. Meskipun demikian, Cina tampak mengabaikan persoalan internal yang dihadapi oleh negaranegara di kawasan Afrika (Chan, 2010).

Dalam investasinya ke Sudan tepatnya di wilayah Darfur, Cina menggunakan soft diplomacy dalam menjalin hubungan yang harmonis dengan pemerintah Sudan. Diplomasi Cina tersebut dibuktikan dengan adanya respon yang sangat baik oleh pemerintah Sudan. Strategi Cina dengan Sudan adalah dengan memberikan bantuan-bantuan yang diperlukan oleh negara-negara di Afrika, khususnya Sudan dengan bantuan dalam bentuk ekonomi, kemanusiaan, serta tidak melakukan intervensi terhadap permasalahan domestik Sudan. Sudan merupakan wilayah yang berpotensi memiliki cadangan minyak yang sangat besar dengan total ekspor 500.000 barel/hari. Hal itulah yang kemudian mendorong Cina merubah haluan kebijakan luar negeri menuju Sudan demi terpenuhinya kesediaan energi minyak untuk menopang kebutuhan industri di dalam negeri.

Afrika seringkali dilihat sebagai sebuah benua yang tertinggal di dunia dikarenakan tingginya jumlah negaranegara yang bermasalah seperti perang sipil yang berkepanjangan di Sudan, kemiskinan dan kelaparan serta rezim otoriter yang seringkali melanggar hakhak asasi manusia. Persoalan domestik tersebut menjadikan Afrika menjadi negara yang rapuh karena terjadi ketidakstabilan dalam berbagai faktor.

Kerapuhan negara dan instabilitas sosial-politik dalam negeri meenjadi celah bagi Cina untuk menjalin kerja sama dengan menawarkan hubungan non-intervensi 
di Afrika, terutama Sudan. Keterbukaan negara-negara di Afrika mendorong Cina untuk melakukan investasi luar negeri secara langsung (Foreign Direct Invesment) dengan nilai yang relatif tinggi kepada pemerintah Sudan. Investasi minyak kepada Sudan tersebut dilakukan dengan melibatkan Badan Usaha Milik Negara (BUMN) Cina, yaitu Cina National Petroleoum Corporations (CNPC). Berdasarkan uraian tersebut, tulisan ini akan mengkaji bagaimana proses investasi langsung dan implikasi yang muncul dari kebijakan Cina terhadap Sudan dalam bidang energi.

\section{TINJAUAN LITERATUR}

Perkembangan sektor ekonomi Cina telah mengalami kenaikan yang pesat dari tahun per tahunnya. Di mana perkembangan ekonomi Cina ini didominasi dengan tingginya jumlah importir minyak secara global hingga melebihi kemampuan produksi dari dalam negeri. Hal ini mendorong Cina untuk melakukan ekspansi ke negaranegara dengan cadangan minyak untuk memenuhi cadangan energinya. Bahkan Cina di sini mengalahkan Amerika Serikat sebagai negara importir minyak terbesar di dunia pada tahun 2015.

Salah satu strategi yang Cina terapkan dalam meningkatkan pertumbuhan ekonominya adalah dengan menggunakan metode Federal
Direct Investment. Di mana FDI di sini memiliki artian jika suatu perusahaan yang berasal dari suatu negara melakukan investasi ke perusahaan yang berada di negara lainnya dalam kurun waktu yang lama. Terdapat beberapa metode yang dilakukan dalam pengaplikasian metode FDI ini sendiri. Yang pertama adalah dengan menanam modal dengan cara membeli perusahaan di luar negeri yang sudah ada atau dapat juga dengan memberikan modal untuk membangun perusahaan baru di negara lain. Metode lainnya dapat dilakukan dengan cara membeli saham dengan sekurang- kurangnya sebesar 10\% (Puriadji, 2017).

Kebutuhan Cina untuk memenuhi cadangan minyak menjadikan negara ini menawarkan bantuan kepada Afrika dengan jumlah US $\$ 3$ miliar sebagai dana pinjaman, US\$2 Miliar sebagai dana piutang ekspor, dan US\$5 miliar sebagai dana investasi dari Cina untuk Afrika (Indah, 2014).

Pemerintah Cina memfokuskan kebijakan luar negerinya justru kepada negara yang mengalami masalah internal seperti Sudan dengan cara memanfaatkan kondisi Sudan untuk memperoleh keuntungan. Sikap Cina terhadap kondisi Sudan ini sendiri menjadi perhatian dunia Internasional. Cina pernah menolak untuk menurunkan pasukannya untuk 
membantu permasalahan HAM yang terjadi di konflik Sudan Selatan lebih tepatnya yang berada di Darfur. Akan tetapi, pihak Cina dengan cepat tanggap menurunkan pasukannya saat terjadi ancaman keselamatan terhadap sumur minyak Cina di Sudan. Karena investasi minyak yang dilakukan Cina ini membuat Cina mengalami pertumbuhan ekonomi yang stabil antara 8-10\% semenjak 1978 yang akan dapat dipertahankan hingga 10 tahun mendatang apabila kecenderungan saat ini dapat dipertahankan (Thomas, 2007). Pada tahun 2011, 20\% keseleluruhan total konsumsi energi Cina bersumber dari minyak bumi (Crompton, 2005).

Secara politik, kerjasama Cina kepada Sudan juga dipengaruhi oleh perubahan sistem ideologi awalnya komunis kini lebih mengarah pada nasionalisme pragmatis. Cina akan melakukan kerja sama dengan siapa pun sejauh memberikan keuntungan bagi pihaknya, bahkan kerja sama tersebut menentang paham akan komunis sendiri. Dalam upaya untuk melangsungkan kerja sama dengan Sudan, Cina telah melakukan lima upaya dengan memberikan bantuan kepada pihak Afrika. Pertama, penetapan dana pembangunan bagi Afrika sebesar US\$5 miliar sebagai bentuk investasi modal perusahaan Cina di Afrika. Kedua, mempersiapkan dana pinjam preferensial sebesar US $\$ 2$ miliar dalam jangka waktu 3 tahun ke depan. Ketiga, penghapusan utang utang negara yang terlilit utang dan terbelakang dalam bentuk utang pemerintah bebas bunga yang jatuh tempo pada tahun 2005 serta melatih 15.000 pekerja profesional Afrika. Keempat, mengirimkan tenaga ahli pertanian ke Afrika sejumlah 100 orang. Kelima, mendirikan 30 rumah sakit, 100 sekolah pedesaan, dan memberikan beasiswa bagi mahasiswa Afrika yang dulunya berjumlah 2000 orang kini menjadi 4000 orang per tahun 2009.

Selain bekerjasama dalam sektor energi, pemerintah Cina juga mengekspor persediaan senjata bagi angkatan bersenjata Sudan. Kerjasama persenjataan ini telah terjalin sejak masa pemerintahan Jafar Nimeiry. Bahkan saat dewan keamanan PBB memberikan embargonya kepada Sudan, Cina tetap memasok persenjataan militer kepada pihak Sudan. Sehingga membuat anggaran pembelanjaan militer Sudan naik dengan pesat.

Kerjasama antara pihak CinaAfrika sendiri terus berlanjut berkembang pada pembangunan infrastruktur transportasi serta aspek produksi di wilayah Sudan. Investasi yang telah dilakukan oleh pemerintah Cina ini sendiri tidak terlepas darikepentingan nasional Cina dengan mengutamakan peran negaranya dalam 
kebijakan "China First" (Setiawan, 2017, p. 2).

Fokus kerjasama energi anatara pemerintah Cina dan Sudan tidak lain bertujuan untuk mempertahankan pertumbuhan ekonomi nasional. Meskipun demikan, adanya perubahan sikap internasional terhadap dan serangan-serangan yang mengancam posisi Cina di Sudan mempengaruhi nilai kerjasama yang telah dilakukan sebelumnya. Data menunjukkan bahwa tingkat impor minyak Cina di Sudan pada tahun 2012 - 2017 mengalami penurunan sejumlah $10 \%$.

\section{KERANGKA ANALISIS}

\section{Teori Ekonomi Politik} Internasional

Keterikatan studi hubungan internasional dan ekonomi mulai menjadi perhatian kalangan akademisi sejak munculnya pendekatan International Political Economy (IPE). Pendekatan Ekonomi Politik Internasional merupakan pandangan yang melihat bagaimana politik dan ekonomi merupakan dua hal yang saling mempengaruhi satu sama lain.

Pendekatan ini mencoba memahami bagaimana aktor politik (negara, individual, dan institusi) mempengaruhi ranah internasional yang berdampak kepada kebijakan dan interaksi ekonomi yang juga kemudian kembali mempengaruhi kebijakan domestik (Spero and Jeffry, 1997, pp.
2-4). Secara singkat Thomas Oatley mendefinisikan IPE sebagai sebuah kajian yang mempelajari bagaimana faktor politik mempengaruhi perkembangan ekonomi global dan bagaimana ekonomi global mempengaruhi politik sehingga dapat menjadi pertimbangan dalam pembuatan kebijakan domestik suatu negara (Oatley, 2016, 1-2).

\section{Konsep National Interest}

Negara adalah aktor penting dalam sistem internasional. Setiap negara di dunia tidak akan lepas dari sebuah kepentingan untuk memenuhi kebutuhan domestik negaranya. Kepentingan ini bermacam-maccam, mulai dari kepentingan untuk mendapatkan kekuasaan, kepentingan ekonomi, dan lain sebaginya. Kepentingan negara yang ingin dicapai dalam sistem internasional itulah yang disebut dengan national interest (Maria Shelly, 2009).

Suatu kepentingan nasional negara adalah hasil dari kepentingan rakyatnya juga. Kepentingankepentingan tersebut terkait dengan kondisi eksternal negara dalam merespon isu-isu yang sedang berlangsung seperti isu ekonomi, politik, budaya agar tetap dapat berperan dalam lingkungan internasional dan dapat mencapai tujuannya (Shelly, 2009). 
Namun, tidak hanya kondisi eksternal saja, kondisi internal juga sangat mempengaruhi misalnya terkait kesejahteraan masyarakat negaranya. Kepentingan-kepentingan eksternal untuk internal negara inilah yang akhirnya dapat membentuk suatu kebijakan luar negeri (Shelly, 2009). Maka dalam konteks penelitian ini, Cina merumuskan strategi diplomatik yang bertujuan untuk memenuhi kebutuhan minyak dalam negeri melalui investasi dengan Sudan.

\section{METODE PENELITIAN}

Metode penelitian yang digunakan dalam penelitian ini adalah pendekatan penelitian kualitatif deskriptif dengan studi kasus investasi Cina ke Sudan. Data-data dan informasi diperoleh dari observasi melalui literatur-literatur yang ada. Argumen-argumen yang ada didalam paper ini juga didukung oleh konten analisis dari dokumen dan konsep yang berasal dari literatur yang ada.

\section{PEMBAHASAN}

\section{Foreign Direct Invesment}

Cina sebagai negara terbesar di Asia Pasifik dan sebagai negara keempat terluas di dunia memiliki jumlah penduduk mencapai 1,3 milyar jiwa. Fakta ini menempatkan Cina sebagai negara yang membutuhkan modal tinggi untuk meningkatkan perekonomian nasional. Pertumbuhan ekonomi Cina begitu signifikan yaitu dari hanya 3,1\% pada tahun 1980 menjadi $16 \%$ pada tahun 2007, sehingga perekonomiannya cukup berpengaruh di dunia. Salah satu strategi Cina dalam meningkatkan perekonomian nya melalui FDI (foreign direct investment). FDI adalah suatu metode dalam sistem ekonomi untuk memberikan investasi oleh perusahaan dari sebuah negara untuk menanamkan modal nya dalam jangka waktu yang panjang ke perusahaan lain di suatu negara. FDI melibatkan dua negara sekaligus, di mana negara asal (bome country) mengendalikan perusahaan negara tuan rumah (host country).

Ada beberapa cara yang dapat dilakukan dalam melaksanakan FDI, pertama penanaman modal ini dilakukan dengan cara melakukan pembelian perusahaan di luar negeri yang sudah ada atau dapat juga dengan menyediakan modal untuk membangun perusahaan baru di negara lain. Selain itu, dapat juga dengan cara membeli saham dengan sekurang-kurangnya sebesar 10\% (Puriadji, 2017).

Pada banyak negara, FDI sangat lazim dilakukan dalam bidang pembelian atau konstruksi pabrik, pembelian tanah sebagai investasi. Investasi langsung yang dilakukan oleh negara asing bersifat penuhkepemilikannya, ini berarti 
negara tersebut dapat dengan mudah mengendalikan dan membuat kebijakan luar negerinya sesuai dengan apa yang diinginkan. Namun, investasi Cina ke Sudan ini termasuk dalam FDI yang bersifat resource seeking, artinya investasi yang dilakukan untuk memperoleh faktor produksi yang lebih efisien di negara lain dibandingkan dengan menggunakan faktor produksi di dalam negeri yang dinilai lebih mahal dan prosesnya lama.

\section{Proses Terjadinya Investasi}

Sudan adalah salah satu negara di Afrika yang sedang dalam masalah. Melihat kesempatan ini, Cina memanfaatkan keadaan Sudan untuk memperoleh keuntungan yang sebesar-besarnya. Cina melakukan investasi besar-besaran di Sudan untuk memenuhi kebutuhan minyak bumi yang sudah menipis di Cina. Cina mengalami pertumbuhan ekonomiyang stabil antara 8-10\% semenjak 1978 yangakan dapat dipertahankan hingga 10 tahun mendatang apabila tren saat ini dapat dipertahankan (Thomas, 2005).

Pada tahun 2011, 20\% daritotal konsumsi energi Cina adalah minyak bumi (Crompton, 2005). Peningkatan minyak bumi diperkirakan akan terus meningkat melihat semakin berkembangnya sektor industri di dunia, Cina sebagai negara yang memiliki potensi peningkatan ekonomi harus mengeluarkan banyak energi minyak bumi. Maka dari itu Cina mencari sumber daya alternatif lain selain batu bara yang sedang dapat perhatian lebih karena penggunaan nya sangat merusak lingkungan, Cina mencari negara yang memiliki cadangan minyak bumi yang besar. Cina sudah tidak dapat mengkonsumsi minya domestik nya sejak tahun 1993. Hal ini mendapat perhatian lebih dari pemerintah, karena jika Cina mencari sumber daya alternatif lain maka itu hanya menutupi sedikit dari konsumsi minyak yang diperlukan Cina. Oleh karena itu, muncul suatu ketergantungan Cina terhadap minyak luar negeri.

Produksi minyak di Cina stabil diangka 2.836.20 thousand barrels per day (tbpd) di tahun 1991 menjadi 3.377 .50 tbpd di tahun 2000 dan terakhir di angka 4.308.40 pada tahun 2010 . Produksi domestik minyak bumi Cina terfokus pada dua sumur minyak terbesar di Cina yaitu di Daqing (Heilongjiang) dan Tarim (Xinjiang). Meski demikian, kebutuhan konsumsi Cina melonjak drastis dari tahun 1991 menuju tahun 2010 dengan $2.498 .80 \mathrm{di}$ tahun 1991 menjadi 8.745 .70 di tahun 2010. Hal ini dapat dijelaskan dengan melihat rata-rata konsumsi minyak bumi di Cina dalam kurun waktu 20 tahun tersebut adalah sebesar 5200 tbpd, jauh di atas produksi domestik Cina (Setiawan, 2017). Konsumsi 
minyak Cina yang besar ini tidak diimbangi oleh produksi minyak domestik yang menyebabkan Cina harus mengimpor minyak bumi yang besar yang perjalanan investasi FDI ini dimulai pada tahun 2009.

\section{Kebijakan "Cina First"}

Kebijakan China First atau mendahulukan kepentingan Cina ini merupakan strategi utama dalam melakukan managemennya di dalam proyek-proyek di Sudan. Hal tersebut dengan jelas menggambarkan bahwa Cina benar-benar berusaha memenuhi kebutuhan nasionalnya, bahkan sampai dengan detail memastikan sumber daya manusia yang dibawa langsung dari Cina untuk meneliti di ladang minyak di Sudan (Deborah, 2010). Tidak lepas dari itu semua yang dilakukan Cina, salah satunya adalah Sudan semata-mata hanya untuk mendapatkan keuntungan yang sebesar-besarnya bagi Cina.

\section{Dampak Investasi Cina}

Tentu saja setelah Cina melakukan kerjasama dengan Sudan, terdapat konsekuensi bagi kedua negara tersebut, jika Cina memperoleh keuntungan dari sumber-sumber minyak bumi di Sudan, maka sebaliknya Sudan sendiri memperoleh pasokan senjata untuk angkatan bersenjata dari Cina yang justru memengaruhi masalah konflik sipil di
Sudan. Meskipun pada tahun 2004 Sudan bagian selatan sudah menemukan perdamaian tetap saja kondisi pasca-konflik masih dipenuhi kecurigaan tinggi di tengah masyarakat Sudan bagian selatan yang membuat CNPC (Cina National Petroleum Company) dan pemerintah Cina khawatir karena sebagian besar sumur minyak yang dikuasai oleh CNPC berada di Sudan bagian selatan. Sudanese People Liberation Army (SPLA) yang mengatasnamakan warga sipil Sudan Selatan menuduh kehadiran Cina memperburuk situasi konflik masyarakat sipil yang berada di wilayah utara dan selatan.

Cina merupakan pemasok utama persenjataan militer Sudan mulai dari amunisi senjata, tank, helikopter dan lain-lain. Semua ini dibayar dengan minyak hasil produksi domestic Sudan. Bukan hanya itu, Cina juga sering memperintahkan Sudan untuk mengirim militernya ke tempat CNPC beroprasi agar dapat menjaga sumur minyak tersebut dari serangan SPLA, dalam penjagaan tersebut Cina juga sering menyelundupkan tentaranya yang tidak menggunakan seragam militer ke dalam barisan tentara Sudan.

Kerjasama Cina dengan militer Sudan menyebabkan terjadinya penyerangan yang dilakukan oleh SPLA terhadap kilang minyak tempat CNPC beroprasi, hal ini dilakukan oleh SPLA demi melemahkan militer 
Sudan dan mengakhiri perang sipil yang terjadi karena pelanggaranpelanggaran HAM yang dilakukan oleh pemerintah Sudan demi membuka lahan pengeboran minyak. Ini menyebabkan publik internasional merespon hal tersebut dan menganggap bahwa Cina sebagai aktor penting dalam perekonomian dunia yang tidak bertanggung jawab dengan membantu pemerintah Sudan dalam pelanggaran HAM. Selain dampakdampak yang tersebut di atas, Sudan juga mendapatkan keuntungan melalui investasi Cina tersebut, dikarenakan Cina tidak hanya serta merta melakukan investasi, namun juga melakukan pembangunan di Sudan seperti sekolah, akses jalan, dan lainlain. Hal tersebut kemudian membuka jalan bagi Cina di mata pemerintah dan masyarakat Sudan.

\section{KESIMPULAN}

Berdasarkan hasil analisa yang dilakukan dengan menggunakan teori ekonomi politik internasional, investasi berbasis minyak Cina di Sudan sangat erat kaitannya dengan kepentingan nasional Cina dengan sejumlah peran. Peranan Cina tersebut digambarkan dalam tiga variabel. Pertama, kepentingan nasional Cina untuk menyediakan suplai minyak untuk mendukung perkembangan ekonomi domestik. Kedua, kebijakan Cina First menjadi patokan Cina untuk memudahkan Cina dalam investasi dengan Sudan dengan melihat kondisi Sudan. Ketiga, terdapat keuntungan timbal balik yang didapatkan oleh Sudan dikarenakan Cina bukan hanya investasi tetapi melakukan pembangunan di wilayah Sudan sebagai upaya diplomasinya tanpa intervensi urusan dalam negeri pemerintahan Sudan.

\section{DAFTAR PUSTAKA}

Chan, S. (2010) 'Cina's Self-Extrication from the Malcca Dilemma and Implications', International Journal of Cina Studies, 1(1), pp. 1-24.

Crompton, P. \& Wui, Y. (2005). 'Energy Consumption in Cina: Past Trends and Future Direction', Energi Economics , Vol. 27, No. 1, pp. 195-208.

Jeffrey, J. (1997) The Politics of International Economic Relations. London: Routledge.

Kusuma, D (2008) China Mencari Minyak: Diplomasi China ke Selurub Dunia 19902007. Depok: Centre for Chinese Studies.

Oatley, T. (2016) International Political Economy. New York: Routledge.

Puriadji, A. (2017) FDI di Indonesia (Online). Available at: https://sbm.binus.ac.id/2017/11/30/ fdi-di-indonesia/ (Diakses: 29 Maret 2019). 